\title{
Evaluation of in vivo techniques for the determination of apparent ileal amino acid digestibilities in feedstuffs for piglets
}

\author{
J. Viljoen, ${ }^{1, *}$ S.E. Coetzee ${ }^{1}$, J.C. Fick ${ }^{1}$, F.K. Siebrits ${ }^{1}$ and J.P. Hayes ${ }^{2}$ \\ ${ }^{1}$ Agricultural Research Council, Animal Nutrition and Animal Products Institute, P/Bag X2, Irene, 0062, South Africa \\ ${ }^{2}$ Department of Poultry Science, University of Stellenbosch, Stellenbosch, 7600, South Africa
}

\begin{abstract}
Three in vivo techniques were evaluated in terms of their suitability for determination of the apparent ileal amino acid digestibility (AID) of protein sources for piglets. The techniques were: ileo-rectal anastomosis (IRA), cannulation at the distal ileum and a slaughter technique. A standard diet and three diets in which $20 \%$ of the standard diet was substituted with either skim milk powder (SMP), fish meal or roasted full-fat soya beans (FFS) were used. Piglets were weaned at 21 days of age, and the respective diets were fed in 24 equal hourly portions per day from days 29-37. Ileal digesta was collected from day 33-37 in IRA and cannulated piglets. Piglets used for the slaughter technique were killed at 37 days of age and ileal digesta was collected. Chromium III oxide was used as an indigestible marker with all three techniques. Although AID means did not differ $(p>0.05)$ between the different techniques, the cannulation technique resulted in the lowest variation (standard error of the mean) of all treatments (8.2 vs 13.7 and 14.1 for the slaughter and IRA-techniques respectively). AID means obtained using the cannula technique were 1.8 percentage units higher for the SMP diet than values obtained using the other techniques $(83.2$ versus $81.4 \%$ ), and up to 9.3 percentage units higher for the FFS diet (75.4 versus $66.1 \%$ ). Growth data suggested that the cannulation technique caused less trauma for the piglets than the IRA-technique. IRA-piglets had not yet regained their initial weaning weight by 37 days of age, while the other piglets gained weight over the trial period. The cannulation technique is the most attractive method for use with piglets in terms of the lower variation in digestibility values. Practical aspects such as ease of handling and sampling, surgical trauma and piglet stress, are also important and contribute to the selection of the cannula technique as the most appropriate.
\end{abstract}

Key words: piglet, amino acids, digestibility, techniques.

*Author to whom correspondence should be addressed. Current address: Kynoch Feeds (Pty.) Ltd., P.O. Box 4880, Randburg, 2125, South Africa; e-mail: hviljoen@feeds.kynoch.co.za.

\section{Introduction}

There has been considerable research on the development of techniques for assaying amino acid (AA) digestibility in pigs. According to Low (1985), the best estimates of the amount of dietary AA absorbed by growing pigs are obtained by measuring apparent or true digestibility. This conclusion was based on the results of trials done with digesta collected from pigs with single or re-entrant cannulae in the distal ileum (before major modification of digesta AA by the microflora takes place). However, digestibility results obtained with growing-finishing pigs do not necessarily apply to piglets. This is emphasised by the results obtained by Bengala Freire et al. (1988), who found age-related differences in digestibility of feedstuffs in post weaning piglets (e.g. nitrogen digestibilities of $67.8 v s$ $80.7 \%$ for a wheat-soybean diet).

Several techniques have been used with piglets to determine AA digestibility in feedstuffs: Li \& Sauer (1994) and Sohn et al. (1994) used a simple T-cannula at the distal ileum of piglets; Bengala Freire et al. (1988) used the ileo-rectal anastomosis (IRA) technique; Leibholz (1985) and Moughan et al. (1989) used the slaughter technique. Few comparisons have been carried out between the different techniques to establish which one would be the most appropriate to determine the AA digestibility of feedstuffs in early-weaned piglets.

In growing-finishing pigs, a number of techniques have already been compared to determine the digestibility of AA. Fuller et al. (1994) compared the ileo-colic re-entrant cannula (IPVC) with the IRA and T-cannula techniques. Overall mean apparent digestibilities of nitrogen and AA were higher for the IPVC (0.83) than for the IRA or cannula techniques, which gave similar mean values $(0.71 \mathrm{vs} 0.74)$. No studies could be found comparing techniques in early-weaned piglets. The success of cannulation and anastomosis techniques also depends on the ability of the piglet to cope with the induced stress. It is therefore necessary to choose a suitable technique which does not cause 
unnecessary stress for the piglet (Köhler, 1992). Three techniques for determining AA digestibility in the piglet were compared: the IRA-technique, cannulation at the terminal ileum and the slaughter technique.

\section{Materials and methods}

\section{Ileo-rectal anastomosis (IRA)}

Crossbred suckling piglets of about 18 days of age were used. The piglets resumed suckling within a few hours after surgery. No problems were observed in respect of acceptance by the sow or littermates. The piglets were surgically modified by a simple end-to-side anastomosis of the ileum to the rectum as proposed by Fuller \& Livingstone (1982) and applied by Hennig et al. (1990) on growing-finishing pigs. Surgery was performed under halothane anaesthesia. After weaning at 21 days of age, piglets were kept individually in kennel-type cages $(0.75 \mathrm{x} 0.75 \mathrm{~m}$, height: $0.40 \mathrm{~m})$ with wire-mesh floors equipped with feed troughs and automatic water nipples. Room temperature was kept at 30 ${ }^{\circ} \mathrm{C}$.

Piglets were adapted to a weaner diet and fed ad libitum (Table 1). This diet was similar in composition to that used by Viljoen et al. (1988). The different test diets (Table 2) were introduced at 28 days of age. No extra mineral and vitamin supplements were given to the IRA-piglets. An indigestible marker (Chromium III oxide) was thoroughly mixed with the diets at an inclusion rate of $5 \mathrm{~g}$ chromium $/ \mathrm{kg}$ (Leibholz, 1985). From 30 days of age the piglets received their respective diets at a rate of $40 \mathrm{~g} / \mathrm{kg}$ body weight (body weight at day 30) per day in 24 equal hourly portions. Feed spillage and body weights were recorded daily during both the adaptation and collection periods. Feed and water were not withdrawn before weighing.

Table 1 Composition of the $\operatorname{diet}^{1}$ fed from weaning at 21 days to 28 days of age

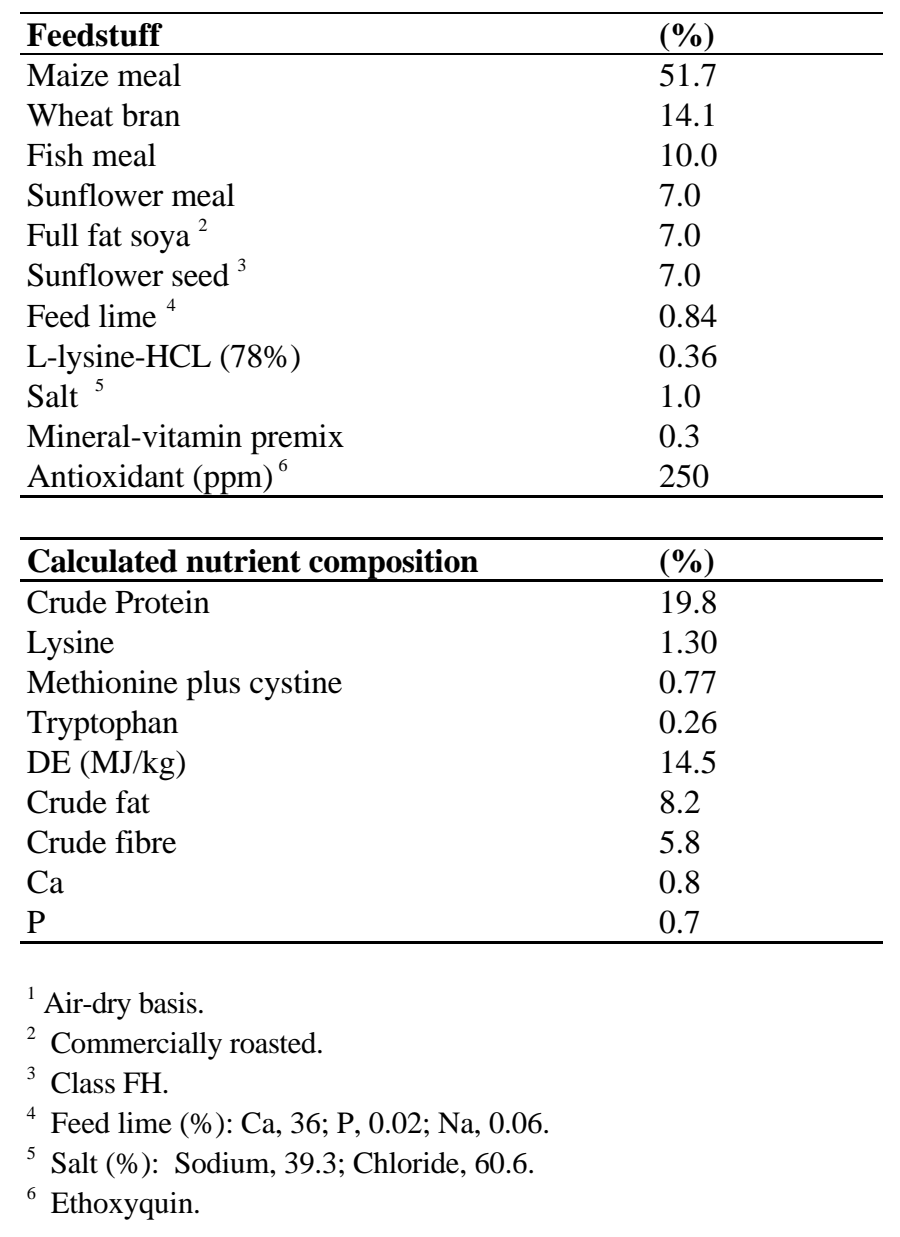


Five to six animals per diet were used. From 33-37 days of age ileal digesta was collected hourly for 24 hours at the rectum using an ileostoma bag bandaged to the piglet. Although total digesta was collected, some spillages occurred, thus necessitating the use of chromium to calculate digesta content. Collected digesta was immediately placed in a freezer at $-10{ }^{\circ} \mathrm{C}$. No preservatives were added. Ileal digesta was kept at $-10{ }^{\circ} \mathrm{C}$ until freeze-dried. After freeze drying, aliquots of daily digesta samples were pooled and mixed to provide a sample representative of the whole collection period. Feed samples and ileal digesta were analysed for dry matter (DM) and nitrogen (N) (AOAC, 1984). Chromium content was determined as described by Cheong \& Salt (1968). Amino acid analyses were carried out on a Beckmann Model 7300 amino acid analyser after samples were hydrolysed in a $2 \mathrm{ml} 6 \mathrm{~N}$ HCL solution in evacuated tubes placed in a pre-heated oil bath at $110^{\circ} \mathrm{C}$ for 22 hours. Samples for methionine analysis were oxidised in $1 \mathrm{ml}$ performic acid overnight before hydrolysis

\section{Cannulation at the distal ileum}

Suckling piglets were fitted with simple T-cannulae (Walker et al., 1986) at the distal ileum at approximately 18 days of age. The piglets were removed from the litter approximately one hour before surgery. Surgery was performed under halothane anaesthesia, and the cannula was inserted in the ileum 3 to $4 \mathrm{~cm}$ proximal to the anterior attachment of the ileo-cecal ligament. An adhesive bandage was used to keep the cannula tightly in place and to prevent leakage, and the cannula was closed with a cork stopper. The protruding part of the cannula was stabilised by wrapping cotton gauze around it and covered with adhesive bandage to protect the piglet from littermate injury. The cannulae were prepared from rigid $50 \mathrm{~mm}$ plastic T-pieces with an internal diameter of $12 \mathrm{~mm}$. The straight part of the Tpiece was halved longitudinally to produce a simple T-cannula with flanges of $20 \mathrm{~mm}$ (total $40 \mathrm{~mm}$ ). The same postoperative procedure and feeding regimen as described for IRA-piglets was followed.

Five to six animals were used for each diet, and representative digesta samples were taken continuously per latex bag from days 33-37 by inserting a snug-fitting tube with a slanted tip into the cannula to divert digesta for collection. The contents of the bags were emptied every hour and stored immediately at $-10{ }^{\circ} \mathrm{C}$. No other preservation procedure was followed. Analytical procedures were as described for the ileo-rectal anastomosis samples.

Table 2 Amino acid composition ${ }^{1}(\%)$ of experimental diets

\begin{tabular}{lllll}
\hline Item & $\begin{array}{l}\text { Standard }^{2} \\
\text { mixture }\end{array}$ & $\begin{array}{l}\text { Fish }^{3} \\
\text { meal }\end{array}$ & $\begin{array}{l}\text { Skim milk }^{4} \\
\text { powder }\end{array}$ & $\begin{array}{l}\text { Full fat }^{5} \\
\text { soya }\end{array}$ \\
\hline Dry matter & 90.6 & 90.6 & 88.0 & 90.5 \\
Crude protein & 8.9 & 20.7 & 12.9 & 14.4 \\
Arginine & 0.44 & 0.88 & 0.55 & 0.90 \\
Cysteine & 0.35 & 0.50 & 0.38 & 0.45 \\
Histidine & 0.22 & 0.46 & 0.34 & 0.36 \\
Isoleucine & 0.21 & 0.47 & 0.45 & 0.48 \\
Leucine & 0.88 & 1.35 & 1.29 & 1.27 \\
Lysine & 0.24 & 0.86 & 0.64 & 0.61 \\
Methionine & 0.21 & 0.47 & 0.34 & 0.29 \\
Phenylalanine & 0.38 & 0.65 & 0.59 & 0.66 \\
Threonine & 0.27 & 0.62 & 0.51 & 0.50 \\
Valine & 0.31 & 0.65 & 0.60 & 0.58 \\
\hline
\end{tabular}

1 Air-dry basis.

$285 \%$ Maize meal $+15 \%$ wheat bran.

$380 \%$ Standard mixture $+20 \%$ fish meal.

$480 \%$ Standard mixture $+20 \%$ skim milk powder.

$580 \%$ Standard mixture $+20 \%$ full fat soya. 


\section{Slaughter technique}

Piglets were weaned at 21 days of age and fed the weaning diet ad libitum (Table 1). The same management and feeding procedures as described for the other techniques were used. At 37 days of age, five or six piglets per test diet were anaesthetised 15 minutes after an hourly feeding (Leibholz, 1985) by intravenous administration of sodium pentobarbitone. The intestinal tract was removed and the ileal digesta (last third of the small intestine) rapidly separated, squeezed out and collected. Digesta was stored at $-10{ }^{\circ} \mathrm{C}$ until freeze-dried. The analytical procedures were similar to those described for the other techniques.

\section{Statistical analysis}

Analysis of variance for all data (complete randomised design) was performed by means of the SAS system using PROC GLM (SAS Institute Inc, 1989). Outlier data points were identified as described by Weisberg (1985). Significance between treatments was tested by means of the Bonferroni T-test at a 95\% probability level.

\section{Results and Discussion}

The average ileal digestibility values and standard errors of the mean (SEM) for $\mathrm{N}$ and essential AA are presented in Tables 3-6.

\section{Accuracy of measurement}

The SEM was used to describe technique-related variation for each experimental diet. Although small, the SEM for the apparent AA digestibility of the standard diet (Table 3) tended to be larger (3.7) for the slaughter technique than for the cannula technique (2.9) or IRA-technique (2.8). SEM values for lysine digestibility values were three times lower with the cannula technique than with the IRA-technique (1.5 vs 4.5), and intermediate with the slaughter technique (3.3). In contrast to lysine, the IRA-technique produced the lowest SEM values for arginine, isoleucine, leucine, phenylalanine and valine when compared to the other two techniques.

Table 3 Apparent ileal amino acid digestibilities (\%) of the standard diet determined by the three different techniques ${ }^{1}$

\begin{tabular}{lllllll}
\hline & \multicolumn{2}{l}{ Technique } & \multicolumn{2}{l}{$\begin{array}{l}\text { Slaughter } \\
(\mathrm{n}=5)\end{array}$} & $\begin{array}{c}\text { IRA } \\
(\mathrm{n}=5)\end{array}$ & \\
\cline { 2 - 7 } & $\begin{array}{l}\text { Cannula } \\
\text { Mean }\end{array}$ & $\mathrm{SEM}^{2}$ & Mean & SEM & Mean & SEM \\
\hline Nitrogen & 54.6 & 2.3 & 45.3 & 4.8 & 49.8 & 6.8 \\
Arginine & 78.1 & 2.8 & 74.9 & 1.9 & 81.8 & 1.5 \\
Histidine & 75.2 & 2.1 & 67.4 & 3.0 & 76.5 & 2.4 \\
Isoleucine & 56.3 & 4.8 & 52.9 & 6.7 & 64.6 & 2.7 \\
Leucine & 74.3 & 2.7 & 66.8 & 3.7 & 76.7 & 1.8 \\
Lysine & 61.8 & 1.5 & 64.0 & 3.3 & 59.1 & 4.5 \\
Methionine & 0.9 & 2.5 & 70.2 & 2.6 & 67.6 & 3.3 \\
Phenylalanine & 69.7 & 2.8 & 63.4 & 4.1 & 73.6 & 2.0 \\
Threonine & 44.2 & 4.1 & 42.6 & 3.1 & 46.9 & 4.5 \\
Valine & 63.1 & 3.3 & 56.8 & 4.6 & 65.5 & 2.6 \\
\hline Average (AA) & 66.0 & 2.9 & 62.1 & 3.7 & 68.0 & 2.8 \\
\hline \hline
\end{tabular}

1 No differences $(p>0.05)$ were found between the three techniques.

${ }^{2}$ Standard error of the mean. 
When $20 \%$ of the standard diet was replaced with SMP (Table 4), fish meal (Table 5) or FFS (Table 6), the cannula technique resulted in the lowest variation for ileal digestibility values. For the SMP treatment, the SEM obtained with the cannula technique (Table 4) was one third of that obtained with the slaughter or IRA-techniques (1.1 compared to 3.7 and 3.2, respectively). Variation in AA digestibility for the standard and SMP diets was larger for the slaughter than for the IRA-technique. The fish meal and FFS diets, on the other hand, gave lower values. Bengala Freire et al. (1988) also used IRA-modified piglets and reported a large variability for $\mathrm{N}$ digestibility. This variation is possibly an inherent characteristic of the IRA-technique.

Table 4 Apparent ileal amino acid digestibilities (\%) of the milk powder based diet ( $20 \%$ milk powder $+80 \%$ basal) determined by the three different techniques ${ }^{1}$

\begin{tabular}{|c|c|c|c|c|c|c|}
\hline & \multicolumn{6}{|c|}{ "Technique } \\
\hline & \multicolumn{2}{|c|}{$\begin{array}{l}\begin{array}{c}\text { Cannula } \\
(n=6)\end{array} \\
\text { a }\end{array}$} & \multicolumn{2}{|c|}{$\begin{array}{c}\text { Slaughter } \\
(\mathrm{n}=6)\end{array}$} & \multicolumn{2}{|l|}{$\begin{array}{c}\text { IRA } \\
(\mathrm{n}=5)\end{array}$} \\
\hline & Mean & SEM $^{2}$ & Mean & SEM & Mean & SEM \\
\hline Nitrogen & 64.9 & 2.9 & 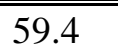 & 4.0 & 63.5 & 2.6 \\
\hline Arginine & 86.0 & 0.9 & 83.2 & 3.5 & 84.2 & 2.7 \\
\hline Histidine & 86.6 & 1.0 & 82.8 & 2.2 & 85.5 & 1.8 \\
\hline Isoleucine & 84.4 & 1.4 & 74.8 & 5.0 & 82.2 & 4.4 \\
\hline Leucine & 84.5 & 1.0 & 76.8 & 3.9 & 82.7 & 2.8 \\
\hline Lysine & 86.0 & 1.1 & 85.4 & 2.9 & 83.8 & 2.7 \\
\hline Methionine & 81.7 & 1.3 & 80.9 & 2.7 & 76.1 & 3.5 \\
\hline Phenylalanine & 82.3 & 1.2 & 74.8 & 4.6 & 82.7 & 2.5 \\
\hline Threonine & 73.6 & 1.0 & 68.3 & 4.6 & 73.9 & 3.8 \\
\hline Valine & 83.5 & 1.0 & 78.7 & 4.2 & 81.8 & 4.4 \\
\hline Average (AA) & 83.2 & 1.1 & 78.4 & 3.7 & 81.4 & 3.2 \\
\hline
\end{tabular}

1 No differences $(p>0.05)$ were found between the three techniques.

${ }^{2}$ Standard error of the mean.

Table 5 Apparent ileal amino acid digestibilities (\%) of the fish meal based diet (20\% fish meal $+80 \%$ basal) determined by the three different techniques ${ }^{1}$

\begin{tabular}{|c|c|c|c|c|c|c|}
\hline & \multicolumn{6}{|c|}{ Technique } \\
\hline & \multicolumn{2}{|c|}{$\begin{array}{l}\text { Cannula } \\
(\mathrm{n}=5)\end{array}$} & \multicolumn{2}{|c|}{$\begin{array}{l}\text { Slaughter } \\
(\mathrm{n}=5)\end{array}$} & \multicolumn{2}{|c|}{$\begin{array}{l}\text { IRA } \\
(n=5)\end{array}$} \\
\hline & $\begin{array}{l}(n=5) \\
\text { Mean }\end{array}$ & $\mathrm{SEM}^{2}$ & Mean & SEM & Mean & SEM \\
\hline Nitrogen & 69.2 & 4.3 & 71.5 & 1.4 & 70.5 & 5.2 \\
\hline Arginine & 86.7 & 1.2 & 82.5 & 2.5 & 83.3 & 3.7 \\
\hline Histidine & 86.5 & 1.2 & 80.8 & 2.5 & 84.7 & 2.7 \\
\hline Isoleucine & 79.1 & 2.4 & 72.6 & 5.1 & 75.7 & 4.4 \\
\hline Leucine & 80.3 & 1.8 & 74.4 & 3.5 & 77.1 & 3.9 \\
\hline Lysine & 84.7 & 1.4 & 85.5 & 2.0 & 83.3 & 1.3 \\
\hline Methionine & 81.3 & 2.0 & 81.9 & 1.7 & 75.5 & 4.2 \\
\hline Phenylalanine & 78.8 & 2.1 & 73.6 & 2.8 & 76.1 & 4.1 \\
\hline Threonine & 72.2 & 3.0 & 67.7 & 3.4 & 67.3 & 4.7 \\
\hline Valine & 77.7 & 2.8 & 74.1 & 3.9 & 71.5 & 5.5 \\
\hline Average (AA) & 80.8 & 2.0 & 77.0 & 3.1 & 77.2 & 3.8 \\
\hline
\end{tabular}

${ }^{1}$ No differences $(p>0.05)$ were found between the three techniques.

${ }^{2}$ Standard error of the mean. 
Table 6 Apparent ileal amino acid digestibilities (\%) of the full fat soya bean based diet ( $20 \%$ full fat soya bean $+80 \%$ basal) determined by the three different techniques ${ }^{1}$

\begin{tabular}{|c|c|c|c|c|c|c|}
\hline & \multicolumn{6}{|c|}{ Technique } \\
\hline & \multicolumn{2}{|c|}{$\begin{array}{l}\quad \text { Cannula } \\
(\mathrm{n}=7)\end{array}$} & \multicolumn{2}{|c|}{$\begin{array}{l}\text { Slaughter } \\
(\mathrm{n}=5)\end{array}$} & \multicolumn{2}{|c|}{$\begin{array}{l}\text { IRA } \\
(n=4)\end{array}$} \\
\hline & Mean & SEM $^{2}$ & Mean & SEM & Mean & SEM \\
\hline Nitrogen & 58.4 & 3.6 & 56.3 & 5.5 & 45.9 & 6.3 \\
\hline Arginine & 84.6 & 1.7 & 82.4 & 1.8 & 79.4 & 2.9 \\
\hline Histidine & 80.0 & 1.8 & 75.1 & 2.7 & 76.3 & 3.0 \\
\hline Isoleucine & 75.6 & 2.9 & 68.8 & 2.9 & 64.3 & 5.2 \\
\hline Leucine & 76.9 & 1.9 & 70.6 & 2.8 & 68.6 & 3.7 \\
\hline Lysine & 75.6 & 1.8 & 76.9 & 2.9 & 65.6 & 6.1 \\
\hline Methionine & 72.8 & 1.8 & 72.3 & 4.6 & 58.3 & 4.5 \\
\hline Phenylalanine & 76.7 & 1.9 & 71.8 & 3.1 & 69.9 & 3.8 \\
\hline Threonine & 62.8 & 2.9 & 58.8 & 4.5 & 50.8 & 5.2 \\
\hline Valine & 74.0 & 2.8 & 68.3 & 3.6 & 61.5 & 5.0 \\
\hline Average (AA) & 75.4 & 2.2 & 71.7 & 3.2 & 66.1 & 4.4 \\
\hline
\end{tabular}

1 No differences $(\mathrm{P}>0.05)$ were found between the three techniques.

${ }^{2}$ Standard error of the mean.

Surgical procedures at 18 days of age and subsequent weaning at 21 days of age retarded growth in the piglets (Table 7) compared to the slaughter technique piglets (no surgery). The cannulated piglets weighed less $(\mathrm{P} \leq$ $0.05)$ than the intact piglets, and tended $(\mathrm{P}>0.05)$ to be lighter than the IRA-piglets at weaning. After surgery, littermates were inclined to play with the cannulae. Proper covering of the cannula solved the problem. At 28 days of age the intact piglets were still heavier $(\mathrm{P} \leq 0.05)$ than modified piglets, while the IRA-modified piglets lost more weight than the cannulated piglets. At 37 days of age the IRA-piglets had not yet regained their weaning weight, while the other piglets gained weight. It appeared that the IRA-modified piglets were more severely influenced by the surgical and collection procedures than the cannulation group. These piglets also had the largest variation in body weight as shown by the coefficients of variation. Bengala Freire et al. (1988) measured feed intake and growth performance, and showed that IRA-modified piglets can be used for experimental purposes as soon as three days after surgery. They also considered the use of these procedures as non-traumatic. The comparative growth results obtained in the current study, however, suggest that the cannulation technique is less traumatic for piglets than the IRA-technique. Furthermore, the emptying of the ileostoma bags on IRA-piglets resulted in much more handling stress than the quick switching of latex bags at the cannula.

Table 7 Live weights $(\mathrm{kg})$ of piglets at different stages of the study

\begin{tabular}{lllllll}
\hline & \multicolumn{3}{l}{ Technique } & & & \\
\cline { 2 - 6 } & $\begin{array}{c}\text { Cannula } \\
\text { Mean }\end{array}$ & CV & $\begin{array}{l}\text { Slaughter } \\
\text { Mean }\end{array}$ & CV & $\begin{array}{c}\text { IRA } \\
\text { Mean }\end{array}$ & CV \\
\hline Weaning (21 days) & $4.68^{\mathrm{a}}$ & 15.02 & $5.65^{\mathrm{b}}$ & 21.12 & $5.03^{\mathrm{ab}}$ & 21.25 \\
28 days of age & $4.70^{\mathrm{a}}$ & 11.72 & $5.55^{\mathrm{b}}$ & 21.64 & $4.47^{\mathrm{a}}$ & 23.38 \\
37 days of age (end of trial) & $4.89^{\mathrm{a}}$ & 11.91 & $6.39^{\mathrm{b}}$ & 22.45 & $4.69^{\mathrm{a}}$ & 28.44 \\
Gain/loss from 21 to 37 days & 0.21 & & 0.73 & & -0.33 & \\
\hline
\end{tabular}

a;b Means within the same row bearing different superscripts differ $(\mathrm{P}<0.05)$.

$\mathrm{CV}$ : coefficient of variation $(\%)$. 
The use of both cannulation and IRA-techniques enabled multiple sampling of digesta on a continuous basis for the chosen period ( 5 days in the current study), while the use of the slaughter technique allows only one digesta sample to be collected at slaughter. Some of these samples were relatively small, which could necessitate the bulking of digesta from two or more piglets. The obvious advantage of multiple sampling renders the two surgical methods more attractive than the slaughter method.

\section{Digestibility values}

The digestibility values of $\mathrm{N}$ and AA for the different treatments are shown in Tables 3-6. Although large numerical differences did occur in digestibility values between techniques, the variation was too large and the number of replicates too few to obtain statistical differences $(\mathrm{P}>0.05)$. However, the average digestibility values for the indispensable AA in the Standard diet (Table 3) were the highest when the IRA-technique was applied (68.0\%), and were only 2.0 percentage units higher than those found with the cannula technique $(\mathrm{P}>0.05)$. The slaughter technique yielded average digestibility values that were 5.9 percentage units lower $(\mathrm{P}>0.05)$ than those obtained with the IRA-technique. Apparent AA digestibility values for the fish meal, SMP and FFS diets were generally higher (1.8 to 9.3 percentage points) for the cannulated piglets than for the other two techniques.

The slaughter technique resulted in the lowest average digestibility values when evaluating the standard and SMP diets. A possible explanation is given by Badaway et al. (1957) and Fell (1961), namely that the shedding of mucosal cells at death into the intestinal lumen may have an influence on the digestibility of nitrogeneous compounds. The physical manipulation of the intestine in order to remove the digesta could have resulted in an additional sloughing of cells, thus adding to the endogenous fraction of digesta. These effects would be most pronounced when evaluating diets low in protein and AA.

The addition of fishmeal to the standard diet (Table 5) yielded similar digestibilities for both the slaughter and IRA-techniques (77.0 and $77.2 \%$, respectively). These values tended to be lower than those obtained with the cannula technique (80.8\%) (P > 0.05). According to Viljoen et al. (1998), the endogenous contribution is not as pronounced when diets high in protein content are fed. The effect of mucosal shedding would thus not be as marked as with sources lower in protein content.

The addition of FFS to the standard diet (Table 6) tended $(\mathrm{P}>0.05)$ to result in lower digestibility values when determined with the IRA-technique compared to that obtained with both the cannulation and slaughter techniques (66.1 for average indispensable AA digestibility compared to 75.4 and $71.7 \%$ respectively). The reason for the low digestibility values found when using the IRA-technique is not known. It can only be postulated that piglets that are subject to such drastic surgical modification are less able to digest a protein source low in digestibility, which is further aggravated by the possible presence of trypsin inhibitor. The transient hypersensitivity response to soya beans in severely stressed early-weaned pigs described by Newby et al. (1984) may furthermore result in poor utilisation of soya products by the piglet. This could result in decreased villus height and increased crypt depth due to a cell-mediated immune response in the intestine (Li et al., 1990).

Fuller et al. (1994) compared the post-valve ileocolic re-entrant (IPVC) technique with the IRA and the Tcannula techniques for the determination of AA digestibility of feedstuffs for growing pigs. The overall mean values for IRA and T-cannula techniques were similar for apparent and true AA digestibilities. The authors mentioned that differences between methods are likely to vary according to the diet tested. Darcy-Vrillon \& Laplace (1990) also compared the IRA-technique with the IPVC-technique. Their results showed that the IRA-technique yielded lower AA digestibility values with high fibre diets, probably due to a lack of ileo-caeco-colic sphincter function. Laplace et al. (1994) compared four surgical procedures with the IRA-technique (end-to-end and end-to-side anastomosis, both with and without the ileo-caeco-colic valve). The results obtained by Laplace et al. (1994) showed that the presence or absence of the valve had no effect on total AA digestion, but that valve function appears to be useful in improving fibre digestion in the small intestine of IRA-pigs. In the current study, the FFS diet had the highest crude fibre content while the IRA-technique was the only one of the three techniques applied where the ileo-caeco-colic valve was not intact and functional. Köhler et al. (1990) showed that cereal-based diets high in fibre yielded digestibility estimates that were 5 to 12 percentage units higher when re-entrant cannulae were used than when T-cannulae were used. Their results and those of Laplace et al. (1994) suggest that passage rate may play a role in feedstuff digestibility. More research is necessary to evaluate the effects of feedstuffs on AA digestibility when using these techniques. 


\section{Conclusions}

Although the AID values obtained did not differ $(\mathrm{P}<0.05)$ between the different techniques, the cannulation technique is the most attractive method for use with piglets because of the lower variation (SEM) associated with estimates of digestibility. Practical aspects such as ease of handling and sampling, surgical severity and piglet stress are also important and contributed to the selection of the cannula method as the most appropriate technique. The feedstuff under investigation must be considered, however, especially in the presence of substances such as antinutritive factors. In this respect, the evaluation of FFS in IRA-piglets could have lead to biased results.

\section{Acknowledgements}

Thanks are extended to the Protein Research Trust for partly funding this study, to the late M. N. Ras, and J. F. Naudè, H. M. Pieters, M. T. Modungwane, A. Mphuloane, Z. Z. Thwala and N. Manyangaza for helping with the execution of the trial, and to G. Putter; F. de Villiers and J. J. Botha who performed the surgery. P. M. Barnes and J. Collier and her personnel are thanked for performing the amino acid and chemical analysis. R. L. C. Coetzer of the Agrimetrics Institute of the ARC is also thanked for performing the statistical analyses.

\section{References}

AOAC, 1984. Official methods of analysis of the Association of Official Analytical Chemists. 14th Ed. Association of Official Analytical Chemists, Washington, D.C.

Badaway, A.M., Campbell, R.M., Cuthbertson, D.P. \& Fell, B.F., 1957. Changes in the intestinal mucosa of the sheep following death by humane killer. Nature 180: $756-757$.

Bengala Freire, J., Peiniau, J., Lebreton, Y. \& Aumaitre, A., 1988. Determination of ileal digestibility by shunt technique in the early-weaned pig: Methodological aspects and utilisation of starch rich diets. Livest. Prod. Sci. 20: 233 - 247.

Cheong, F.H. \& Salt, F.J., 1968. A rapid wet-digestion method for the determination of chromic oxide in faeces. Laboratory Practice 17: 199.

Darcy-Vrillon, B. \& Laplace, J.P., 1990. Digesta collection procedure may affect ileal digestibility in pigs fed diets based on wheat bran or beet pulp. Anim. Feed Sci. Technol. 27: $307-316$.

Fell, B.F., 1961. Cell shedding in the epithelium of the intestinal mucosa: fact and artefact. J. Pathol. and Bacteriol. 81: $251-254$.

Fuller, M.F., Darcy-Vrillon, B., Laplace, J.P., Picard, M., Cadenhead, A., Jung, J., Brown, D. \& Franklin, M.F., 1994. The measurement of dietary amino acid digestibility in pigs, rats and chickens: a comparison of methodologies. Anim. Feed Sci. Technol. 48: 305 - 324.

Fuller, M.F. \& Livingstone, R.M., 1982. Annual report of studies in animal nutrition and applied sciences. Rowett Research Institute, pp. 39.

Hennig, U., Wünsche, J., Souffrant, W.B. \& Hermann, U., 1990. Use of ileorectostomy and fistulation on pigs for studies into prececal digestion of crude protein and amino acid absorption. Arch. Exper. Vet. Med. 44: 3544.

Köhler, T., 1992. Evaluation of techniques to collect ideal digesta in pigs. PhD Thesis, Department of Animal Nutrition, Wageningen Agricultural University, Wageningen, The Netherlands.

Köhler, T., Huisman, J., Den Hartog, L.A. \& Mosenthin, R., 1990. Comparison of different digesta collection methods to determine the apparent digestibilities of the nutrients at the terminal ileum in pigs. J. Sci. Food Agric. 53: 465 - 475.

Laplace, J.P., Souffrant, W.B., Hennig, U., Chabeauti, E. \& Fevrier, C., 1994. Measurement of preceacal dietary protein and plant cell wall digestion in pigs; comparison of four surgical procedures for ileo-rectal anastomosis. Livest. Prod. Sci. 40: 313-328.

Leibholz, J., 1985. An evaluation of total and digestible lysine as a predictor of lysine availability in protein concentrates for young pigs. Brit. J. Nutr. 53: 615 - 624 .

Li, D.F., Nelssen, J.L., Reddy, P.G., Blecha, F., Hancock, J.D., Allee, G.L., Goodband, R.D. \& Klemm, R.D., 1990. Transient hypersensitivity to soybean meal in the early-weaned pig. J. Anim. Sci. 68: 1790.

Li, S. \& Sauer, W.C., 1994. The effect of dietary fat content on amino acid digestibility in young pigs. J. Anim. Sci. 72: 1737-1743.

Low, A.G., 1985. Amino acid use by growing pigs. In: Recent Developments in Animal Nutrition. Eds. Cole, D.J.A. \&. Haresign, W., Butterworths, London. pp. 108-123 
Moughan, P.J., Wilson, M.N., Smits, C.H.N. \& Smith, W.C., 1989. An evaluation of skim milk powders subjected to different heating conditions during processing as dietary protein sources for the young pig. Anim. Feed Sci. Technol. 22: 203-215.

Newby, T.J., Miller, B., Stokes, C.R., Hampson, D. \& Bourne, F.J., 1984. Local hypersensitivity to dietary antigens in early-weaned pigs. In: Recent Advances in Animal Nutrition. Eds. Cole, D.J.A. \&. Haresign, W., Butterworths, London.

SAS Institute Inc, 1989. SAS/STAT users guide, Version 6, Fourth Edition, Volume 2. NC-SAS Institute Inc., Cary, $\mathrm{NC}$.

Sohn, K.S., Maxwell, C.V., Southern, L.L. \& Buchanan, D.S., 1994. Improved soybean protein sources for earlyweaned pigs: II Effects on ileal amino acid digestibility. J. Anim. Sci.. 72: 631-637.

Viljoen, J., Ras, M.N. \& Coetzee, S.E., 1988. Class FH sunflower seeds (Helianthus annuus) as an energy/protein source for early-weaned piglets. S. Afr. J. Anim. Sci. 18: 59-62.

Viljoen, J., Ras, M.N., Hayes, J.P. \& Siebrits, F.K., 1998. Apparent and true amino acid digestibilities of feedstuffs in pigs employing the total ileal content (tic) technique and the mobile nylon bag (mnbt) technique. Livest. Prod. Sci. 53: 205-215.

Walker, W.R., Morgan, G.L. \& Maxwell, C.V., 1986. Ileal cannulation in baby pigs with a simple T-cannula. J. Anim. Sci. 62: 407-411.

Weisberg, S, 1985. Applied linear regression, Second Edition. John Wiley and Sons Inc, New York. 